九州大学学術情報リポジトリ

Kyushu University Institutional Repository

\title{
Designing a Green Human Resource Management Model at University Environments: Case of Universities in Tehran
}

Shahriari, Bahareh

Faculty of Management, Payame Noor University

Hassanpoor, Akbar

Faculty of Management, Kharazmi University

Navehebrahim, Abdolrahim

Faculty of Management, Kharazmi University

Jafar, Saeedinia

Faculty of Management, Kharazmi University

https://doi.org/10.5109/4068612

出版情報：Evergreen. 7 (3)，pp.336-350，2020-09. 九州大学グリーンテクノロジー研究教育センター バージョン：

権利関係 : 


\title{
Designing a Green Human Resource \\ Management ${ }^{1}$ Model at University Environments: Case of Universities in Tehran
}

\author{
Bahareh Shahriari ${ }^{1}$, Akbar Hassanpoor ${ }^{2, *}$, Abdolrahim Navehebrahim², Saeed Jafar \\ inia $^{2}$ \\ ${ }^{1}$ Faculty of Management, Payame Noor University, Iran \\ ${ }^{2}$ Faculty of Management, Kharazmi University, Iran \\ *Author to whom correspondence should be addressed: \\ E-mail: a.hassanpoor@khu.ac.ir
}

(Received December 5, 2019; Revised August 22, 2020; accepted September 11, 2020).

\begin{abstract}
Due to environmental changes around the world, the importance of green issues is getting more attention nowadays and because human resources ${ }^{2}$ are the most important resource of any organization, one of the issues to be considered is green human resource management. The purpose of the current research was to provide a basic understanding of green human resource management, designing a green human resource management model at university environments, and acquaintance it with its dimensions, components, and features using the grounded theory approach. This research has made a significant contribution to the development of information on this case as well as to a model for green human resource management. The statistical population of this study, according to its subject area, was universities experts (academic managers and professors), sampling was done using the purposive method and the sample size was 19 people also, to analyze the data obtained from the interviews, a three-step process of open coding, pivot coding, and selective coding were used. The components of each category were extracted based on the grounded theory approach and a conceptual model was developed and based on the results, green human resource management was extracted in the form of six main categories: core factors, causal factors, contextual factors, intervening factors, strategies, and consequences.
\end{abstract}

Keywords: Green Human Resource Management, Green University, Grounded Theory

\section{Introduction}

Nowadays, environmental sustainability and green organization topics have shaped the principles of green human resource management $t^{1,2,3,4,5)}$. Further, organizational strategies for environmental management and sustainable development will succeed when they are well-aligned with its human resource practices ${ }^{6,7,8)}$. Since individuals are the most important resource in the organizations and since human resources can be scarce in organizations and exploited, sustainability has become a concern for those who are interested in the areas of individuals in organizations, at work, and in the human resource management ${ }^{3}$ systems. The human resource sustainable management seeks to reproduce the human resource base (potential human stock) during the time and simultaneously, achieve organizational goals, and strive to meet beneficiaries' needs ${ }^{9}$. Researches have shown how the role of human resource management is effective in reducing environmental degradation. For example, it has been examined how green HRM bestead along with financial and environmental performance outcomes through national culture, stakeholder conflict-theories with a green perspective on employee recruitment, competition, and participation ${ }^{10)}$. Therefore, green HR has some operations with a special focus on waste management, recycling, carbon effects reduction, production and use of green commodities and certainly, most employees think about the environment highly and have a great association and job satisfaction rather than the one who is always there for the green to emerge. Because the green HR is an effort to meet requirements so that a balance to be done between the organizational growth for the production of wealth and the preservation

\footnotetext{
${ }^{1}$ GHRM

${ }^{2} \mathrm{HR}$

${ }^{3}$ HRM
} 
of the natural environment to create a sustained and successful future ${ }^{11)}$. Patil \& Sarode $(2018)^{12)}$, mentioned the role of $\mathrm{HR}$ in developing the sustainability and protecting natural resources and also investigated the role of managers in different levels of an organization and their staff in implementing green behavior and even it causes growth, well-being and employee health ${ }^{13)}$, the balance between financial performance and environmental protection $^{14)}$ so, it should not be overlooked that green employees promote the social identity of organizations, and it is essential to absorb and train the potentials in this area $^{4)}$.

On the other hand, organizations are increasingly seeking to integrate green goals, strategies, and operations development. However, organizations cannot achieve the intended results of their initiatives on green goals completely without the motivated and skilled force. Employing such, efforts by the staff requires the active leadership and involvement of those human resources departments responsible for establishing staff selection, training, evaluation, and rewarding systems ${ }^{15}$.

According to the conducted studies, in Iran, especially in university, it is necessary to turn to green human resource management and take it seriously. Shahriari et al., (2019) by the revision of the previous researches concluding that the main gaps in the research on green human resources management are the cultural gap, lack of comprehensive research in undeveloped countries, and the absence of a cross-cultural model. For example, Tavakkoli et al., (2018), Rajabpour (2017), Seyed Javadin et al., (2017) and Mohammad Nejad et al., (2017) have pointed to the existence of few studies in this area in Iran and the lack of a codified program. Mishra (2017), Masri \& Jarron (2017), Tariq et al., (2016); Mohd Yusuf et al., (2015), Wagner (2013) and Renwick et al., (2012) have stated that most of the researches on human resource management are in developed countries, European countries and the United States. Also, Gholami et al., (2016), Subramaniana et al., (2016), Opatha and Arulrajah (2014) respectively have referred to the lack of comprehensive research in Malaysia, China, and Sri Lanka. Cheema et al., (2015) also pointed to the lack of sufficient knowledge of the benefits of green human resource management in Pakistan was a major gap knows. On the other hand, a lack of a mutually international model has been mentioned by Tang et al., (2018), Patil and Sarode (2018), Subramaniana et al., (2016) and Cheema et al., $(2015)^{16,17)}$. Given that each country has its own economic, social, political, and cultural position, the dimensions and components, causal factors affecting green human resource management and ultimately its guidelines and consequences may vary from country to another country and each country needs a model of green human resource management in its implementation and usage as a native process. Therefore, we need a model that fits with the internal rules and regulations. It is essential that the universities also look at green HRM factors and their consequences based on the campus environment and existing culture. Therefore, researchers focused on indigenous components and designed their model accordingly. By identifying the key factors affecting green HRM, this model assists universities in implementing and utilization of green HRM and poses positive consequences for them, which not only affect staff but also the students. It promotes a green culture in the campus environment and transmits it to the family environment.

Accordingly, the purpose of the current research is also to provide a basic understanding of green HRM, to investigate the causal, contextual, intervening factors, its components, strategies, and consequences and ultimately to design a green HRM model. Besides, this research also has a significant contribution to the development of information and declaration of a model for green HRM. This model assists Universities in the utilization and implementation of green HRM through the selection and recruitment of green staff (increasing virtual screening rather than face-to-face interviews and recruitment of environmental support staff); training and evaluation of green performance (training in green principles observation and performance evaluation based on green standards); participation and compensation for green services (participation of individuals in green programs and decisions that increase their commitment and responsibility and reward commensurate with a green performance that reinforce the individual's motivations); and dissemination of green culture (green universities are more prestigious which is a competitive advantage and causes attracting more highly skilled human resources). In general, it can reduce waste, environmental degradation, the costs of excessive energy consumption, and increase profitability even for all other organizations. In the following, the concept of green HRM and related prior researches, green university, and its consequences have been discussed.

\section{Literature Review: Developing the Concept of GHRM and Green University}

\subsection{Green Human Resource Management (GHRM)}

The term "green human resource management" is a new concept for the majority of academic and professional human resource specialists introduced by Wehrmeyer in 1996 in a book entitled "Greening People: Human Resources and Environmental Management"18). In subsequent years, other studies were also conducted by other researchers, including Jackson et al., (2011) ${ }^{3)}$, Renwick et al., (2008, 2010, 2012, 2016) ${ }^{19,20,4,10)}$, Jabbour et al., (2010) $)^{5)}$ and Ehnert (2009) $)^{9}$.

Different authors have provided various definitions of green human resource management, some of them will be as follows.

- Green HRM refers to policies, operations, and systems that empower employees in organizations due to 
the benefit of the individual, community, environment, and business. Also, green HRM refers to all activities involved in the development, implementation, and maintenance of a system that its purpose is the existence of the organization's green personnel. Turning regular employees into green employees is a human resource management task, intending to achieve the environmental goals of the organization and ultimately achieving a significant share of environmental sustainability that addresses policies, practices, and systems that are beneficial for the individual, society, nature and the business environment. The goal of green HRM is to create, enhance, and maintain greenness in each employee of the organization $^{21)}$.

- GHRM is responsible for the creation of awareness, informing, and establishment of interactions between the employees, especially regarding environmental issues. Also, through green policymaking, it orients the employees towards fulfilling their green duties ${ }^{22}$.

- The research findings of Joong Kim et al., (2019) on hotel employees show that green human resource management enhances employees' organizational commitment, their eco-friendly behavior, and hotels' environmental performance ${ }^{23)}$.

- Leidner et al., (2019) highlighted that Green HRM practices are not peripheral, intermediate, or embedded but shaped by contextual situations. They also revealed that the sustainability advocates (i.e. the leader and managers) intentions do not seem to match Green HRM policy design. Hence, they recommended that practitioners need to consider contextual factors when selecting suitable Green HRM policies ${ }^{24)}$.

- Thu Pham \& Paille (2019), in their research, point out that the behaviors of job seekers should be determined during the selection process in order to understand their pro-environmental attitudes and values ${ }^{25)}$.

- Human Resources Management is directly responsible for the creation of a green workforce that understands, appreciates and practices the Green Initiative and apply its green goals throughout the HRM process in the areas of recruitment, selection, training, reward, growth, and development, promotion and protection of human capital $^{26)}$.

- Green HRM focuses on employee's behaviors towards the environment in the company, which even causes employees to apply such a pattern of consumption in their lives ${ }^{27)}$.

- Mohd Yusef (2015) believes that GHRM is a complex set of the following counts: A- Electronic GHRM: 1electronic recruitment, 2-e-mails, 3- electronic training, 4electronic users, and 5- electronic job description; BFlexible Work including 1- a part-time job, and 2- working at home; C- Social responsibility including 1- recycling, 2- social responsibilities, and 3- green cafeteria; D- Green Policies including 1- security, well-being, consideration for the environment, and 2-green organizational policies (ISO 14001-2); E- Additional care programs including
Mothers' rooms and parking lots, and 2- Childcare room ${ }^{28)}$. Therefore, human resource management is a resolution that helps create a green workforce that can understand and appreciate green culture within the organization. Such a green initiative can use its green goals throughout the HRM process in the fields of recruitment, selection, training, compensation, growth, and development, maintenance, and retention of the company's human capital $^{29)}$, that the functions are summarized in Table 1:

Table 1. Summary of GHRM Functions ${ }^{21)}$

\begin{tabular}{|c|c|}
\hline Job Analysis & $\begin{array}{l}\text { Considering environmental dimensions } \\
\text { as a duty in the job description } \\
\text { Considering green competency as a } \\
\text { special component in conditions for } \\
\text { recruitment }\end{array}$ \\
\hline Recruitment & $\begin{array}{l}\text { Considering the environmental criteria in } \\
\text { recruitment notices } \\
\text { Relating to the concerns of employees } \\
\text { regarding environmental issues }\end{array}$ \\
\hline Selection & $\begin{array}{l}\text { Selection of applicants who are well } \\
\text { aware of green issues in their jobs } \\
\text { Selection of applicants who in their } \\
\text { personal lives behave as green consumers }\end{array}$ \\
\hline socialization & $\begin{array}{l}\text { Familiarizing the new employees with } \\
\text { the organization's green activities } \\
\text { Development for socialization } \\
\text { programs related to green citizenship } \\
\text { behavior for current employees }\end{array}$ \\
\hline $\begin{array}{l}\text { Training and } \\
\text { performance } \\
\text { evaluation }\end{array}$ & $\begin{array}{l}\text { Proper statement of knowledge and skill } \\
\text { regarding green roles through the training } \\
\text { programs designed in this regard } \\
\text { Consideration for separate components } \\
\text { for progression in the context of } \\
\text { greenness through reviewing the } \\
\text { performance feedbacks }\end{array}$ \\
\hline $\begin{array}{c}\text { Reward } \\
\text { management }\end{array}$ & $\begin{array}{l}\text { Providing financial incentives for } \\
\text { employees who have undertaken their } \\
\text { green tasks in their jobs well } \\
\text { Granting non-financial rewards such as } \\
\text { venerating and introducing the green } \\
\text { employees }\end{array}$ \\
\hline $\begin{array}{c}\text { Discipline } \\
\text { management }\end{array}$ & $\begin{array}{l}\text { Compilation and publication of rules } \\
\text { related to greenness } \\
\text { Development of an advanced disciplinary } \\
\text { system for the punishment of employees } \\
\text { who violate green rules }\end{array}$ \\
\hline
\end{tabular}

Regarding the research background, the authors in their previous research titled "a systematic review of green human resource management" reviewed previous researches. The results showed eight major gaps such as the lack of comprehensive studies about GHRM in undeveloped countries and Asia; the absence of a crosscultural model; the lack of long term comparison between sustainable companies and unsustainable ones, lack of attention to rewards for green activities and how to 
motivate green HR; lack of up to date green training, little attention to green leadership, disconnection between the behavior of managers and GHRM and lack of sufficient financial and non-financial and there have been 24 effective factors in the GHRM performance such as knowledge of benefits of GHRM motivation, green organizational learning, social responsibility, green management and leadership support of green ideas and activities, organizational attitudes and culture and so on and they concluded with a review of GHRM functions that the most focus has been on selection and recruitment, training and development functions and the less on discipline management and socialization functions ${ }^{16)}$.

\subsection{Green University}

Universities are the most important sectors of the communities because of their main role in educating the specialist. Therefore, it is substantial to know about the impact of green HRM in the university to utilize the green HRM functions to have a better workplace and educational environment. Green University is commonly recognized worldwide as a place where all its activities are based on the vision of sustainable development and reflect the important responsibility for community development, $\mathrm{too}^{30)}$. The Green University principle focuses on the green education system firstly, that means, the use of the concept of sustainability in education. Tsinghua (a leading green university in China), through its formal and informal green education efforts, commits itself to students becoming responsible citizens and expanding the scope of social responsibility to achieve sustainability. In Tsinghua, green education includes green curriculum, student green training, and green learning environment ${ }^{31)}$. Accordingly, a Green University in Iran has also threedimensional approaches, which are as follows:

-The first dimension is the reduction of the public and current costs of the university as predicted in Iran's economic, social, and cultural development plans.

-The second dimension is the Promotion of educational behavior based on new and paperless technology.

-The third dimension is to train a generation of scholars and graduates who are tracking the consequences of their performance in the environment ${ }^{32}$.

It is necessary to mention that the use of green human resource management can reduce environmental degradation, excessive energy consumption, and increase profitability. For example, the following can be observed:

- Use of educational software and CDs as much as possible, instead of textbooks that reduce paper consumption.

- Use of online training to reduce the costs of energy consumption that brings more benefit for the concern organization and transportation decrease that result in cutting the fuel consumption and air pollution down.

- Use both sides of the paper in writing, printing, and copying (it reduces the power consumption and preserves trees).
- Using public transport or sharing cars whenever possible (it reduces fuel consumption and air pollution).

- More and more efficient use of electronic technology such as holding distance conferences to reduce traveling, which results in decreasing organization costs and air pollution. Also, use computers, tablets, and so on instead of recording information on paper.

- Shut down the computer when not in use (it will reduce electricity consumption and air pollution).

- Use of natural light and work with a minimum number of lamps (it reduces electricity consumption).

- Use of the plants in the workroom and classroom to absorb contamination

- Having your glass and dishes that reduce the consumption of disposable containers.

- Turn off air conditioners before the daily work time (30 minutes before ending work time) ${ }^{21}$.

- The use of reed valves instead of disposable glasses, which reduces both financial costs and environmental pollution that implemented at Payame Noor University.

To achieve the purpose of research and data collection following the process of grounded theory, research questions include:

1) What are the key components and core factors of green human resource management at the university?

2) What are the causal factors of Green Human Resource Management at the university?

3) What are the contextual factors of green HRM at the university?

4) What factors are intervening in managing green $H R$ at the University?

5) What are the Human Resource Management strategies at the university?

6) What will be the consequences of green HRM at the university?

\section{Methodology}

This study has a qualitative approach that collects and analyzes data by the grounded theory research strategy. The grounded theory procedures are designed to develop a set of coherent concepts that provide a complete theoretical explanation of the social phenomenon of study. A grounded theory should explain as much as it describes. Like the other qualitative methods, the data of the grounded theory can come from a variety of sources. Grounded theorizing is a qualitative method that aims to identify and understand people's experiences of events in a particular context ${ }^{33)}$. This study is developmental research because it seeks to present a green HRM model by identifying core factors, causal, contextual and intervening factors, strategies, and consequences that aim to develop knowledge in this area, and it is based on the interpretive paradigm. After all, it addresses the views of experienced and expert individuals to answer the research question and the interpretation of their views has shaped this model.

The data collection tool was an in-depth interview with 
the statistical population to the extent that received enough information and then the information was duplicated. The statistical population of this study was university experts (university administrators and professors) concerning its subject area, people who are influential, well known, and conscious in their field of work. This study interviewed the managers of university departments active in the field of green affairs. The interviewees were people with more than 5 years of experience in the green field, knowledgeable in green affairs, observing green issues about their staff or at the university scope, and with postgraduate education.
Priority was given to the managers and deputies of these departments as detailed in Table 2. The sampling method is also purposive, which means the purposive selection of research units to acquire knowledge or information ${ }^{34)}$ in which among the sample units, the individuals with the most knowledge and information about the subject under study were selected and interviewed. The sample quantity of this study was 19 persons and to analyze the obtained data from interviews, the three steps of open coding, pivot, and selective coding process of grounded theory were used.

Table 2. Interviewee’s Characteristics

\begin{tabular}{|c|c|c|c|c|}
\hline Item & Corporate Responsibility & Frequency & $\begin{array}{c}\text { Experience } \\
\text { (years) }\end{array}$ & Sexuality \\
\hline \multirow{3}{*}{1} & \multirow{3}{*}{ Head of University } & \multirow{3}{*}{3} & 25 & \multirow{3}{*}{ male } \\
\hline & & & 25 & \\
\hline & & & 27 & \\
\hline \multirow{3}{*}{2} & \multirow{3}{*}{$\begin{array}{l}\text { Vice President of Administration and } \\
\text { Finance of the University }\end{array}$} & \multirow{3}{*}{3} & 18 & \multirow{3}{*}{ male } \\
\hline & & & 18 & \\
\hline & & & 21 & \\
\hline \multirow{3}{*}{3} & \multirow{3}{*}{ University Educational Assistant } & \multirow{3}{*}{3} & 25 & \multirow{3}{*}{ male } \\
\hline & & & 17 & \\
\hline & & & 15 & \\
\hline \multirow{2}{*}{4} & \multirow{2}{*}{ Head of the college } & \multirow{2}{*}{2} & 34 & \multirow{2}{*}{ male } \\
\hline & & & 21 & \\
\hline \multirow{3}{*}{5} & \multirow{3}{*}{ Department Manager } & \multirow{3}{*}{3} & 22 & \multirow{3}{*}{ male } \\
\hline & & & 18 & \\
\hline & & & 15 & \\
\hline \multirow{2}{*}{6} & \multirow{2}{*}{ Department Vice-president } & \multirow{2}{*}{2} & 13 & \multirow{2}{*}{ male } \\
\hline & & & 12 & \\
\hline \multirow{2}{*}{7} & \multirow{2}{*}{ Expert } & \multirow{2}{*}{2} & 8 & male \\
\hline & & & 5 & female \\
\hline 8 & HR Advisor & 1 & 8 & male \\
\hline
\end{tabular}

\section{Findings}

Information analysis process in Grounded Theory is based on three Stages of Open Coding (Creating Concepts and Categories), pivotal Coding (Identifying pivotal categories, causal factors, Contextual factors, Intervening factors, strategies, and outcomes) and selective Coding (creating theory) which is explained below the formation modality of the derived categories from the concepts. The open coding and the coding of the interviews will be explained first, and then the formation modality of the concepts and categories will be discussed.

\subsection{Initial Coding}

At this stage, efforts were made to extract the key points and the items that the interviewees emphasized more on them from the interviews. These key points can be summarized from the interviews, or the researcher himself selects such topics with his creativity and features. Some of the initial codes extracted from the sample of the eleventh interview illustrated in Table 3.

Table 3. Initial Codes of interview No. 11

\begin{tabular}{|l|l|}
\hline \multicolumn{1}{|c|}{ samples of interview transcript } & \multicolumn{1}{c|}{ Initial code } \\
\hline $\begin{array}{l}\text { Encouraging and motivating people is essential to driving green } \\
\text { ideas }\end{array}$ & Encourage green innovation \\
\hline
\end{tabular}




\begin{tabular}{|l|l|}
\hline $\begin{array}{l}\text { There should be regulations at the university on green matters and } \\
\text { encouragement and supervision of staff in green affairs }\end{array}$ & $\begin{array}{l}\text { The necessity of green HR regulations } \\
\text { at university }\end{array}$ \\
\hline $\begin{array}{l}\text { University policy and evaluation need to be changed annually and } \\
\text { green affairs also should be taken into account }\end{array}$ & $\begin{array}{l}\text { The necessity to replace green politics } \\
\text { at university }\end{array}$ \\
\hline The monitoring system must be in place & Green monitoring \\
\hline $\begin{array}{l}\text { Regarding green transport, people get together and going on a } \\
\text { mission by the same care in one day and people with same way use } \\
\text { the same car }\end{array}$ & Green transport \\
\hline $\begin{array}{l}\text { Have a printer in each department and sharing it with the others in } \\
\text { the building. My offer is still pending }\end{array}$ & $\begin{array}{l}\text { The need to pay attention to and apply } \\
\text { green ideas }\end{array}$ \\
\hline The manager himself must also be trained to be supportive & Emphasize managers green training \\
\hline There is no sense of green responsibility and culture in society & $\begin{array}{l}\text { The need for increasing the sense of } \\
\text { green social responsibility }\end{array}$ \\
\hline $\begin{array}{l}\text { At Green University, staff are more committed to staying in the } \\
\text { mood is consistent with the atmosphere }\end{array}$ & $\begin{array}{l}\text { The loyalty of Green Staff at Green } \\
\text { University }\end{array}$ \\
\hline $\begin{array}{l}\text { We have to make a paperless theme and launched the electronic } \\
\text { archive and we do not print any longer for the record }\end{array}$ & Managers support of green ideas \\
\hline $\begin{array}{l}\text { office automation has also accelerated matters, reducing costs and } \\
\text { paper consumption }\end{array}$ & $\begin{array}{l}\text { The impact of office automation on } \\
\text { paper savings and costs }\end{array}$ \\
\hline
\end{tabular}

\subsection{Secondary Coding and category formation}

At this point, the initial codes become secondary codes due to their large number, meaning that the researcher goes on to describe the words of each code, compares the codes with one another to identify overlapping and similar codes, and then converts the secondary codes into conceptual codes. Table 4 presents the results based on the secondary code, concepts, and categories.

\subsection{Selective Coding and final model}

At this stage, the pivotal codes of the previous stage were grouped and the final table of variables related to each of them was prepared from the expert's and universities' points of view as presented in Table 5. Then, the final model of research is then formed as shown in figure 1 .

Table 4. Initial Codes of interview No. 11

\begin{tabular}{|c|c|c|}
\hline Subcategory & Concept & Secondary Code \\
\hline \multirow{5}{*}{$\begin{array}{l}\text { Green HRM } \\
\text { Functions }\end{array}$} & Green recruitment and hiring & $\begin{array}{l}\text { The Importance of Choosing Green People - Influencing Green } \\
\text { Life Skills in employment - recruitment and hiring green people }\end{array}$ \\
\hline & Green Education and Development & $\begin{array}{l}\text { The necessity of green training courses for staff and managers - } \\
\text { Importance of staff green empowerment - Importance of having } \\
\text { green knowledge by university staff - Pay attention to increase of } \\
\text { staff green awareness - Importance of green skills in university } \\
\text { staff }\end{array}$ \\
\hline & Green Performance Management & $\begin{array}{l}\text { Green Performance Assessment - Careful Supervision of Green } \\
\text { Performance - Importance of Proper Supervision of manager on } \\
\text { Green Actions - Proper Identification of Green Employees - } \\
\text { Importance of a Green Career Path for Green Staff }\end{array}$ \\
\hline & $\begin{array}{l}\text { Green Service Rewards and } \\
\text { Compensation }\end{array}$ & $\begin{array}{l}\text { The necessity of Green Reward - Impact of non-financial } \\
\text { incentives for doing green affairs- Impact of financial incentives } \\
\text { for doing green affairs }\end{array}$ \\
\hline & Green motivation & $\begin{array}{l}\text { The necessity to motivate manpower towards green goals - } \\
\text { Encourage green employees - Necessity of managers to support } \\
\text { green employees - Importance of reprimand and negative reaction } \\
\text { to non-conformity of green issues - Need to see green employee }\end{array}$ \\
\hline
\end{tabular}




\begin{tabular}{|c|c|c|}
\hline & & $\begin{array}{l}\text { actions by managers - Importance of motivating staff- Importance } \\
\text { of green staff retention - The role of wage in green staff loyalty } \\
\text { to the university }\end{array}$ \\
\hline $\begin{array}{l}\text { Green Strategic } \\
\text { Thinking }\end{array}$ & $\begin{array}{l}\text { University Human Resources } \\
\text { Green Policy and Strategy }\end{array}$ & $\begin{array}{l}\text { Existence of green HR regulations at the university - Existence } \\
\text { of green HR program at the university - Having a green HR policy } \\
\text { and strategy at the university }\end{array}$ \\
\hline $\begin{array}{l}\text { Formation and } \\
\text { operation of the } \\
\text { Green Committee at } \\
\text { the University }\end{array}$ & Green Team & $\begin{array}{l}\text { Aligning individual goals with green management goals at } \\
\text { university - The importance of having a green team at university - } \\
\text { Setting managers as the role model by staff }\end{array}$ \\
\hline $\begin{array}{c}\text { University } \\
\text { manager's support }\end{array}$ & Role of managers support & $\begin{array}{l}\text { The necessity for Managers to Support Green Programs - } \\
\text { Managers' care to Green Management Standards at the University }\end{array}$ \\
\hline $\begin{array}{l}\text { Board of } \\
\text { trustees/stakeholders } \\
\text { support of the } \\
\text { university }\end{array}$ & $\begin{array}{l}\text { The Role of Supporting Senior } \\
\text { Policymakers }\end{array}$ & $\begin{array}{l}\text { Trustees Need to Support All Green Plans - Need to Invest in Green } \\
\text { Affairs at University - Trustees Support of Green Plans }\end{array}$ \\
\hline Green leadership at & Leadership style of managers & $\begin{array}{l}\text { Influence of management or leadership style - Influence of } \\
\text { manager's attitude on the workforce - Need to pay attention to } \\
\text { qualitative indicators in attitude change - Managers' willingness }\end{array}$ \\
\hline & Participation in Green Affairs & Being involved in Greenery Affairs \\
\hline & Green innovation & Care about green innovation \\
\hline $\begin{array}{l}\text { Meritocracy at } \\
\text { university }\end{array}$ & Meritocracy & $\begin{array}{l}\text { The individual's selection should be based on their capabilities, not } \\
\text { relationships }\end{array}$ \\
\hline \multirow{3}{*}{$\begin{array}{l}\text { University Green } \\
\text { Vision and } \\
\text { perspective }\end{array}$} & University Green Perspective & $\begin{array}{l}\text { The necessity of having a green vision and perspective by the } \\
\text { manager - role of green belief and attitude in employees - the role } \\
\text { of green belief and attitude in managers - foresight }\end{array}$ \\
\hline & University Mission & $\begin{array}{l}\text { The Impact of University Cultural Policy on Advancing Green } \\
\text { Goals }\end{array}$ \\
\hline & University Approach & $\begin{array}{l}\text { The Role of Stability in Green Approach in Managers - The Role } \\
\text { of Managers Except in Advancing Green Affairs - Organizational } \\
\text { Approach to Human Resources - The Role of Employee } \\
\text { Mobilization in Green Affairs }\end{array}$ \\
\hline $\begin{array}{l}\text { Green university } \\
\text { rules }\end{array}$ & $\begin{array}{l}\text { Existence of supporting the } \\
\text { regulation of green management }\end{array}$ & Having green regulations at university \\
\hline University Brand & Organizational brand & Impact of a green brand in green people attraction \\
\hline $\begin{array}{l}\text { University staff } \\
\text { attitudes }\end{array}$ & The green vision of staff & $\begin{array}{l}\text { Influencing the attitude of the workforce on the manager - the } \\
\text { employee's imitation from each other }\end{array}$ \\
\hline Staff awareness level & Awareness level of staff & $\begin{array}{l}\text { The level of human resource awareness of green principles in the } \\
\text { organization }\end{array}$ \\
\hline \multirow[t]{2}{*}{$\begin{array}{l}\text { Staff personality } \\
\text { type }\end{array}$} & Staff personality type & $\begin{array}{l}\text { Paying attention to the importance of the impact of the personality } \\
\text { of human resource on doing green affairs }\end{array}$ \\
\hline & $\begin{array}{l}\text { Keep up with the technology of the } \\
\text { world }\end{array}$ & $\begin{array}{l}\text { Technology advancement and its use - the optimal use of resources } \\
\text { - They need for high-speed Internet }\end{array}$ \\
\hline
\end{tabular}




\begin{tabular}{|c|c|c|}
\hline $\begin{array}{l}\text { University } \\
\text { Technological } \\
\text { context }\end{array}$ & Using electronic systems & $\begin{array}{l}\text { The impact of using office automation - the role of the ERP } \\
\text { system in promoting green goals }\end{array}$ \\
\hline \multirow{2}{*}{$\begin{array}{l}\text { University's cultural } \\
\text { context }\end{array}$} & Organizational Culture & $\begin{array}{l}\text { Type of University Culture - The Role of University Professors in } \\
\text { Green Culture - The Role of Green Culture in Implementing Green } \\
\text { Affairs }\end{array}$ \\
\hline & $\begin{array}{l}\text { Social Responsibility and } \\
\text { Citizenship Behavior }\end{array}$ & $\begin{array}{l}\text { Employee Sense of Social Responsibility - Impact of staff } \\
\text { Citizenship Behavior on Green affairs Observations - Employee } \\
\text { Sense of Green Responsibility }\end{array}$ \\
\hline Empowering context & Learning and self-control & $\begin{array}{l}\text { Empowering and habituating human resources to doing green } \\
\text { affairs - Creating the necessary framework for green regulations } \\
\text { enforcement at the university - The need for experts within the } \\
\text { organization - The need to apply new ideas at the university }\end{array}$ \\
\hline Financial context & University financial constraint & $\begin{array}{l}\text { The Impact of University Budgeting on Green Goals - The Role of } \\
\text { Financial Limitation in Turning to Green Management - The Need } \\
\text { for Cost Reduction }\end{array}$ \\
\hline \multirow[t]{2}{*}{ Structural context } & Size and structure of the university & $\begin{array}{l}\text { The impact of the overall structure of the university on the } \\
\text { implementation of green affairs - size of organization - degree of } \\
\text { integration and separation of university departments }\end{array}$ \\
\hline & The role of flexible structure & $\begin{array}{l}\text { The necessity of flexibility of organization structure - Necessity of } \\
\text { a stable work environment in the university }\end{array}$ \\
\hline \multirow{2}{*}{ Macroeconomic } & Economic conditions of society & $\begin{array}{l}\text { Economic conditions of society - the need for adequate } \\
\text { government funding - need more infrastructure in densely } \\
\text { populated cities }\end{array}$ \\
\hline & Unemployment & $\begin{array}{l}\text { The Negative Impact of Unemployment in the Community on } \\
\text { Green Employment }\end{array}$ \\
\hline \multirow{3}{*}{ Social environment } & Cultural and social tendencies & $\begin{array}{l}\text { People's Lifestyle - Negative Impact of Bureaucratic and } \\
\text { Aristocratic Culture in Society - Role of Community Culture - Role } \\
\text { of Family in Green Culture }\end{array}$ \\
\hline & Green culture in society & $\begin{array}{l}\text { Pre-employment green education in the community - The } \\
\text { importance of public awareness of green issues in the community } \\
\text { by IRIB }\end{array}$ \\
\hline & Demographic factors & The Role of Women in Greenery (Gender) - Age - Education \\
\hline \multirow{3}{*}{ Legislative bodies } & The general policy of the country & $\begin{array}{l}\text { Macro-country policy - Changing the country's policies towards } \\
\text { the green - Government supportive role for the green universities - } \\
\text { State education policy support for the green process - The role of } \\
\text { the state policy towards the development of the environment }\end{array}$ \\
\hline & Country laws and regulations & $\begin{array}{l}\text { Protecting Green Laws in the State - Obstacles to State Law - } \\
\text { Impact of Legislative body (Ministry of Science) - Significance of } \\
\text { State Employment Law Support for Green Employment - Taxation } \\
\text { Support for Green Universities - Changing Financial Audit Process }\end{array}$ \\
\hline & Management weakness of officials & $\begin{array}{l}\text { The superficiality of the authorities - the contradiction of the words } \\
\text { and the actions of the authorities - the fading of substitution in } \\
\text { society }\end{array}$ \\
\hline
\end{tabular}

4 Enterprise Resource Planning 


\begin{tabular}{|c|c|c|}
\hline & $\begin{array}{l}\text { Ministry of Science, Research and } \\
\text { Technology }\end{array}$ & $\begin{array}{l}\text { The necessity of strict supervision of the Ministry of Science on } \\
\text { the green affairs of the universities - Impact of the green vision of } \\
\text { the Ministry of Science - Support of the Ministry of Science on } \\
\text { green creativity }\end{array}$ \\
\hline $\begin{array}{l}\text { Geographical } \\
\text { conditions }\end{array}$ & Geographical conditions & $\begin{array}{l}\text { Geographical conditions of regions - Impact of regional climate on } \\
\text { the implementation of green policies }\end{array}$ \\
\hline $\begin{array}{l}\text { Private or public } \\
\text { university }\end{array}$ & Private or public university & $\begin{array}{l}\text { Difference between Private University Management with Public } \\
\text { one - Optimal Investment - More Monitoring and Motivation at } \\
\text { Private University - Negative Impact of Paying State University } \\
\text { Salaries on Government Budget on Green Motivation }\end{array}$ \\
\hline \multirow{4}{*}{$\begin{array}{l}\text { The motivation of } \\
\text { university staff }\end{array}$} & Financial rewards & $\begin{array}{l}\text { Prioritizing Financial Rewards to Encourage \& Create Green } \\
\text { Motivation - Returning the Benefits of Green Savings to Green } \\
\text { Staff }\end{array}$ \\
\hline & Non-financial rewards & $\begin{array}{l}\text { Prioritizing non-financial rewards for encouraging green human } \\
\text { resource }\end{array}$ \\
\hline & Encouraging staff & $\begin{array}{l}\text { Positive incentive system after green education - priority of } \\
\text { encouragement instead of punishment - implementation of } \\
\text { symbolic green programs such as planting at university }\end{array}$ \\
\hline & Punishment of delinquent staff & Consider punishment and negative reinforcement for the offender \\
\hline \multirow{4}{*}{$\begin{array}{l}\text { Formulation of } \\
\text { green laws and } \\
\text { standards }\end{array}$} & Green Regulations & $\begin{array}{l}\text { Full support of university laws for implementation of green HRM } \\
\text { functions - Green strategy development in the university - } \\
\text { Existence of strategic green HRM - Green standards development } \\
\text { appropriate to the university }\end{array}$ \\
\hline & Clarification & $\begin{array}{l}\text { Prioritizing Green Employees promotion - Separation and } \\
\text { Transparency of Payrolls from the other expenses - Setting } \\
\text { Quantitative Standards for Green affairs observation - - Necessity } \\
\text { to clarify the results of green compliance - Transparency and } \\
\text { honest training of employees on green affairs }\end{array}$ \\
\hline & Green Investment & $\begin{array}{l}\text { Importance of investment in university green affairs - management } \\
\text { and budget allocation for green affairs utilization - design and } \\
\text { construction of a green building - development of electronic and } \\
\text { mechanized platform }\end{array}$ \\
\hline & Outsourcing & Outsourcing some cases towards green goals \\
\hline \multirow{5}{*}{$\begin{array}{l}\text { Green education and } \\
\text { culture }\end{array}$} & Prioritize green education & $\begin{array}{l}\text { First, green education, then strict oversight of implementation - } \\
\text { green management training to the manpower at university - green } \\
\text { education priority in in-service training courses - being green } \\
\text { training courses tailored to human resource needs }\end{array}$ \\
\hline & $\begin{array}{l}\text { The need for green education for } \\
\text { managers }\end{array}$ & Prioritize green education for executives themselves \\
\hline & $\begin{array}{l}\text { create an understanding of the } \\
\text { value of green HRM }\end{array}$ & $\begin{array}{l}\text { Considering the importance of green human resource management } \\
\text { not just because of the economic benefits }\end{array}$ \\
\hline & Emphasize Innovation & $\begin{array}{l}\text { Applying Employee Green Ideas - Creating a Green Offer System } \\
\text { at the University }\end{array}$ \\
\hline & $\begin{array}{l}\text { Disseminate green corporate } \\
\text { culture }\end{array}$ & Managers' emphasis on green culture Dissemination \\
\hline
\end{tabular}




\begin{tabular}{|c|c|c|}
\hline \multirow{2}{*}{$\begin{array}{c}\text { Design of green } \\
\text { monitoring systems }\end{array}$} & The need for continuous monitoring & $\begin{array}{l}\text { Monitoring must be continuous - Hint of green affairs in the } \\
\text { workplace by green people }\end{array}$ \\
\hline & $\begin{array}{l}\text { Managers support of green } \\
\text { supervision }\end{array}$ & Seriousness in evaluating green performance by managers \\
\hline $\begin{array}{l}\text { Green employment } \\
\text { priority }\end{array}$ & Green employment priority & Prioritize green hiring \\
\hline \multirow{3}{*}{$\begin{array}{l}\text { Increasing the } \\
\text { quality of working } \\
\text { life }\end{array}$} & Increase in job satisfaction & $\begin{array}{l}\text { Increasing Human Resource Satisfaction - Increasing Human } \\
\text { Welfare }\end{array}$ \\
\hline & Motivation Increase & Increasing motivation in the workforce \\
\hline & $\begin{array}{l}\text { Improving the quality of working } \\
\text { life }\end{array}$ & $\begin{array}{l}\text { Paying more attention to HR health - HR relaxation - Increasing } \\
\text { employees morale - Increasing employees vitality - Impact of } \\
\text { green programs on quality of work-life - Enjoying work in a green } \\
\text { work environment }\end{array}$ \\
\hline University flexibility & $\begin{array}{l}\text { Increase of organizational } \\
\text { flexibility }\end{array}$ & $\begin{array}{l}\text { Increasing University Variability - Increasing Human Resources } \\
\text { Creativity }\end{array}$ \\
\hline \multirow{3}{*}{$\begin{array}{l}\text { Facilitating the } \\
\text { recruitment and } \\
\text { retention of green } \\
\text { elites and staff }\end{array}$} & $\begin{array}{l}\text { recruitment of elites and expert } \\
\text { professionals }\end{array}$ & Increase in green staff recruitment \\
\hline & $\begin{array}{l}\text { Facilitation of the maintenance of } \\
\text { green staff }\end{array}$ & $\begin{array}{l}\text { The Positive Impact of a Green Brand on Preserving Green } \\
\text { Employees }\end{array}$ \\
\hline & $\begin{array}{l}\text { Promotion of organizational } \\
\text { commitment }\end{array}$ & Increase of green staff commitment \\
\hline $\begin{array}{l}\text { Improving } \\
\text { university } \\
\text { organizational } \\
\text { identity }\end{array}$ & $\begin{array}{l}\text { organizational identity } \\
\text { improvement }\end{array}$ & $\begin{array}{l}\text { Getting Better organizational image - building green beliefs across } \\
\text { the university - enhancing green identity at the university }\end{array}$ \\
\hline $\begin{array}{c}\text { Enhancing student } \\
\text { satisfaction }\end{array}$ & Increasing student satisfaction & Increasing student satisfaction \\
\hline \multirow{4}{*}{ Economic savings } & $\begin{array}{l}\text { Preserving the balance between the } \\
\text { financial and environmental aspects }\end{array}$ & $\begin{array}{l}\text { The balance between financial performance and environmental } \\
\text { protection }\end{array}$ \\
\hline & Return of resources and benefits & Return of resources and benefits \\
\hline & Expanding green behaviors & $\begin{array}{l}\text { Pay more attention to green environment and building- Use of } \\
\text { economically equipped facilities - Use of solar energy }\end{array}$ \\
\hline & reduction in costs & $\begin{array}{l}\text { Reduction of fuel costs- No waste on disposable items- } \\
\text { Reduction of energy consumption - Reduction of paper } \\
\text { consumption - a decrease of university financial costs }\end{array}$ \\
\hline $\begin{array}{l}\text { Developing a green } \\
\text { organizational } \\
\text { culture }\end{array}$ & $\begin{array}{l}\text { Promote green culture at the } \\
\text { university }\end{array}$ & $\begin{array}{l}\text { Promote green culture from home to work- The Positive Impact of } \\
\text { Green people on the Promotion of Green Culture at the University } \\
\text { - Managerial Support on the Promotion of Green Culture - The } \\
\text { Positive Impact on Green Employment and the Promotion of Green } \\
\text { Culture }\end{array}$ \\
\hline $\begin{array}{l}\text { Sustainable } \\
\text { environment }\end{array}$ & Environmental Protection & $\begin{array}{l}\text { Caring for environmental protection - reducing air pollution - } \\
\text { expanding green transportation - reducing traffic }\end{array}$ \\
\hline $\begin{array}{l}\text { Promoting a green } \\
\text { social culture }\end{array}$ & Promotion of green social culture & $\begin{array}{l}\text { Spreading green culture from work to family - promoting a green } \\
\text { lifestyle in the community }\end{array}$ \\
\hline
\end{tabular}




\begin{tabular}{|c|c|l|}
\hline \multirow{2}{*}{} & Green citizenship behavior & $\begin{array}{l}\text { Expanding Green Citizenship Behavior in the Community - } \\
\text { Increasing the sense of green responsibility in the community }\end{array}$ \\
\cline { 2 - 3 } & Get native model & Having a native green cultural model \\
\hline Self-esteem & Trying to be self-confident & Creating self-esteem in employees \\
\hline
\end{tabular}

Table 5. Forming the Main Classes

\begin{tabular}{|c|c|}
\hline Main category & Subcategory \\
\hline $\begin{array}{l}\text { The causal organizational } \\
\text { and managerial factors }\end{array}$ & $\begin{array}{ll}\text { - } & \text { University manager's support } \\
\text { - } & \text { Board of trustees/stakeholders support of the } \\
\text { - } & \text { university } \\
\text { - } & \text { University brand } \\
\text { - } & \text { Green leadership at university } \\
\text { - } & \text { University green vision and perspective } \\
\text { - } & \text { Meritocracy at university } \\
& \text { Green university rules }\end{array}$ \\
\hline The causal individual factors & $\begin{array}{ll}- & \text { University staff attitudes } \\
- & \text { Staff awareness level } \\
- & \text { Staff personality type } \\
\end{array}$ \\
\hline The core factors of GHRM & $\begin{array}{ll}\text { - } & \text { Green human resource management functions } \\
\text { - } & \text { Strategic thinking } \\
\text { - } & \text { Formation and activity of the green committee at } \\
& \text { university }\end{array}$ \\
\hline The contextual factors & $\begin{array}{ll}- & \text { University’s technological context } \\
\text { - } & \text { University’s cultural context } \\
\text { - } & \text { Empowering context } \\
\text { - } & \text { Financial context } \\
\text { - } & \text { Structural context } \\
\end{array}$ \\
\hline The intervening factors & $\begin{array}{ll}- & \text { Macroeconomic } \\
- & \text { Social environment } \\
\text { - } & \text { Legislative bodies } \\
\text { - } & \text { Private or public university } \\
\text { - } & \text { Geographical conditions } \\
\end{array}$ \\
\hline Strategies & $\begin{array}{ll}\text { - } & \text { The motivation of university staff } \\
\text { - } & \text { Formulation of green laws and standards } \\
\text { - } & \text { Green education and culture } \\
\text { - } & \text { Design of green monitoring systems } \\
\text { - } & \text { Green employment priority } \\
\end{array}$ \\
\hline The academic consequences & $\begin{array}{ll}\text { - } & \text { Increasing the quality of working life } \\
\text { - } & \text { University flexibility } \\
\text { - } & \text { Economic saving } \\
\text { - } & \text { Developing a green organizational culture } \\
\text { - } & \text { Facilitating the recruitment and retention of green } \\
& \text { elites and staff } \\
\text { - } & \text { Improving university organizational identity } \\
\text { - } & \text { Enhancing student satisfaction }\end{array}$ \\
\hline The social consequences & $\begin{array}{ll}- & \text { Promoting a green social culture } \\
- & \text { Sustainable environment } \\
\end{array}$ \\
\hline The individual consequence & - $\quad$ Self-esteem \\
\hline
\end{tabular}


The causal organizational and managerial factors:

University manager's support, board of trustees/stakeholders support of university, university brand, green leadership at university, university green vision and perspective, meritocracy at university, green university rules

The causal individual factors:

University staff attitudes, staff awareness level, staff personality type

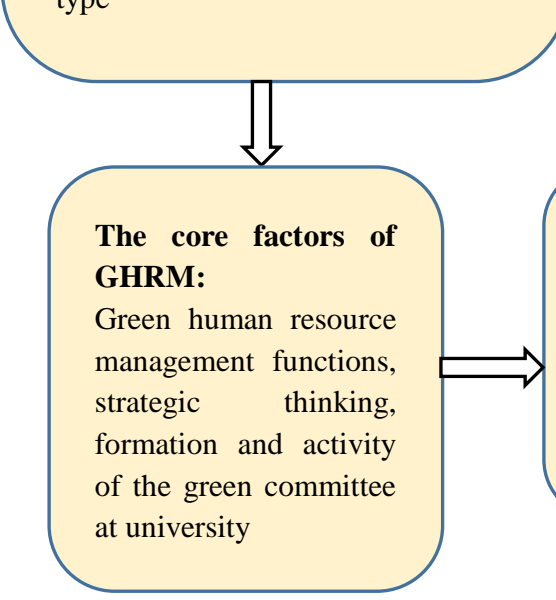

\section{The intervening factors: \\ Macroeconomic, (egislative bodies, private or public university, geographical conditions}

\section{Strategies:}

Motivation of university staff, formulation of green laws and standards, green education and culture, design of green monitoring systems, green employment priority

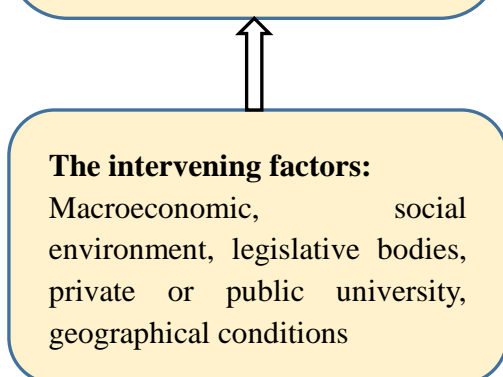

Fig. 1: The final model
The academic consequences:

Increasing the quality of working life, university flexibility, economic saving, developing green organizational culture, facilitating the recruitment and retention of green elites and staff, improving university organizational identity, enhancing student satisfaction

The social consequences:

Promoting green social culture, sustainable environment

The individual consequence: Self-esteem

\section{Research validation}

Strauss and Corbin (2012) have proposed acceptability criteria for evaluating research based on grounded theory, rather than validity and reliability. Acceptability means to what extent the findings of the research are credible in reflecting the experiences of the participants, the researcher, and the reader concerning the phenomenon under study; for this purpose, 10 indicators have been used for acceptability criteria ${ }^{33)}$ :

1) Relevance: Are the findings consistent with the experiences of the experts in the field under study as well as the participants? In this study, individuals were purposefully selected for the interview. People who have the experience, knowledge regarding the research process and care about green issues at university, at home, and in the community.

2) Applicability or usefulness of findings: Do the research findings provide new insights and be applicable? In this regard, the findings of the present study can be useful for designing a model of green HRM for use in universities that have not been implemented, so far; as well as helping to have a native model in this area. In this study, designing green HRM models in pivotal factors, causal factors, contextual and intervening factors, the strategies and consequences have been recognized that will help universities in its implementation and utilization. At the macro level, identifying the intervening factors offers a new horizon for improving green HRM.

3) Concepts: The findings of the research should be able to provide appropriate conceptualization. As can be seen in the findings of the present study, concepts such as a green committee, green team, green leadership, learning and self-control, self-esteem, financial and environmental balance, etc. are examples of concepts that are well conceptualized.

4) Contexts: The findings without context are incomplete. Without context, the reader cannot understand the cause of events. The findings of the present study are based on experiences and events related to green HRM and in this respect, emerging concepts are based on green context and culture. 
5) Logic: Do the storylines have a logical relationship with each other? To meet this criterion, as can be seen in the text of the interviews in the appendix, the narrative process of the Green HRM experience has been attempted to ensure that the narrative in question has a well-ordered and well-timed procedure.

6) Depth: Spacious description of the details enriches the research findings. In this research, it is attempted to present research findings in the process of narration of the emerging theory in detail and concerning its features and dimensions.

7) Deviation: Are there any deviations within the findings? In this respect, it should be noted that if the research data do not match the subject matter, they place it in the range of other characteristics. In this study, due to the theoretical sensitivity, it is desirable to use subjectrelated data desirably.

8) Innovation: Does research have anything new to say or does it bring out the same old ideas in a new vein? Regarding this criterion, it should be noted that the findings of this study have been particularly innovative in designing a green HRM model. As recognized in reviewing previous studies and prior research results, the present study is innovative because no research has been done so far and it has been tried to design a suitable model for the university.

9) Sensitivity: Has the researcher been sensitive to the research topic, the participants, and their findings and taken them seriously? In this research, the researcher was sensitive to the research topic, the participants, and its findings and took them seriously and during the research process, it was attempted to make the subject matter important and sufficiently serious and pay close attention to the details.

10) Citation of notes: Because the researcher cannot recall all the topics, opinions, insights, and declarations in the process of analyzing the findings, the use of notes is necessary. In this case, the researcher has also attempted to cite extracts from the data and transcripts of the interviews as necessary in the narrative process of green HRM experience.

Moreover, to further confirm the research results; the researcher presented the final model of this study to seven interviewees that approved it.

\section{Discussion}

In this research, Green Human Resource Management has been extracted in the form of six main categories, by the grounded theory that in the field of causal factors, two subcategories of causal organizational and managerial factors university manager's support, the board of trustees/stakeholders support of the university, university brand, green leadership at university, university green vision and perspective, meritocracy at university, green university rules and individual causal factors including university staff attitudes, staff awareness level, staff personality type have been derived. The core factors of green HRM are also illustrated by the three indicators of green HRM functions, strategic thinking, formation, and operation of the green committee at the university. The contextual factors include technological, cultural, empowering, financial and structural contexts of the university and the intervening factors are also extracted as macroeconomic, social environment, legislative bodies, private or public university and geographical conditions that in this regard, environmental and organizational characteristics with the five components affected on the strategy which has been identified by the 5 components of the motivation of university staff, formulation of green laws and standards, green education and culture, design of green monitoring systems, and green employment priority. Besides, the consequences of green HRM including academic consequences accompany seven components of Increasing the quality of working life, university flexibility, economic saving, developing green organizational culture, facilitating the recruitment and retention of green elites and staff, improving university organizational identity, enhancing student satisfaction. Social consequences with two components of promoting green social culture, a sustainable environment, and individual outcomes with one component of self-esteem were achieved.

As the core of green HRM is the human resource of all organizations and organs and on the other hand is a new concept for the majority of academic and professional HR professionals, managers and staff of organizations, it is conceptualized as the functions of green HRM, strategic thinking, and the formation and operation of the Green Committee.

\section{Conclusions}

Workplace and in the social environment, regarding the influential environment outside the university, one suggestion is that it is better if the culture starts first with the family because then the manpower with the green culture embedded in it enters the university or organization, which it also reduces the cost of education. On the other hand, it is suggested that by incorporating green education programs or green management courses in universities for students, they should be familiar with some of the green issues that need to be observed before entering the workplace and then enter the market with green attitudes. Of course, for the sake of cultural debate, some also argue that the law must first be established, followed by continuous monitoring to ensure proper behavior is repeated. Therefore, it is recommended that appropriate green laws be considered at both the university and community levels and that regular followup with appropriate encouragement and punishment should be instituted to implement them.

In the workplace within the university, it is also important to pay more attention to in-service training and to incorporate green learning into the human resources curriculum. It is also suggested that quantitative standards 
be set to assess green performance and pay more attention to the green performance of the workforce, and that points be given to individuals' green performance in performance appraisals and ultimately reward. On the other hand, every single green employee must be identified and rewarded with the person who has been in charge of the green, as well as the offender identified and punished. Besides, it is recommended that the payroll be separated from the costs so that the income from the savings are given to the people who have been in charge of the green affairs and to motivate the staff. On the other hand, the implementation of electronic HRM will be very effective.

In this study, interviewees believed that private universities perform better in terms of green practices, for some reasons: failure of the government to allocate and monitor the green budget, poor management of public university on green issues due to the lack of public funding, and receipt of perpetual specific remuneration per month and non-participation or very low share of government executives in profits from green compliance, it is suggested that the government, in addition to its green support for government agencies, oversee spending and compliance with their green affairs as the budget dedicated to green affairs is spent solely on these issues and that offshore agencies are also severely affected.

It is also necessary to take appropriate steps to address the problem of non-protection of the law from prioritizing the recruitment of green people in green universities by the relevant legislative body, and Employment regulations for green universities should give priority to hiring people who have a green vision and desire to work at a green university.

Contextual and interventionist factors that to be considered are needed budget providing and concerning about financial issues for having up-to-date technology and environmentally-friendly equipment that limits the universities. One of the suggested solutions is tax discount and tax organization support for the green university.

Based on the obtained outcomes, the long-term keeping

\section{References}

1) J. Gonzalez-Benito and O. Gonzalez-Benito, “A review of determinant factors of environmental proactivity,” J. of Buss. Strg and the Environment, 15 87-102 (2006). http://dx.doi.org/10.1002/ (ISSN) 1099-0836.

2) A. Marcus and R. Fremeth, "Green management matters regardless," Academy of Mgmt Perspectives, 23 (3) 17-26 (2009).

3) S. E. Jackson, D. W. S. Renwick, C. J. C. Jabbour and M. Muller-Camen, "State-of-the-Art and Future Directions for Green Human Resource Management: Introduction to the Special Issue," German J. of Research in HRM, 25 (2) 99-116 (2011). Doi: 10.1688/1862-0000_ZfP_2011_02_Jackson.

4) D. Renwick, T. Redman and S. Maguire, "Green human resource management: a review and research track of green issues will be profitable, and the savings will go back to the university or any organization that respects green affairs. It suggests that from this return on capital, funds to be allocated for the deployment and installation of new and environmentally friendly equipment that will contribute to the health and well-being of employees in the workplace. On the other hand, it can also be a motivating lever for keeping track of green jobs, as human resources see that observing green affairs also saves money and increases the quality of their working lives in the long term.

One of the causal factors affecting green human resource management is the support of managers, managers need to have a green vision and support the green HR. The importance of focusing on innovation and green ideas should also not be overlooked and employees should have the opportunity to comment and brainstorm and the manager should support the most appropriate and top green ideas. Attention to the green issues to be certain when managers themselves have the green faith and to be trained on them, so we need to have green managers before we have green hiring or training. This applies even to government officials and legislators.

Given the efforts made to develop a green HRM model in this research and its novelty, there may be some shortcomings in this research. Therefore, it is suggested that quantitative methods of the aforementioned model in universities and organizations be also evaluated. On the other hand, there is a need for more research into the role of being private and public universities and even other organizations in the observance and implementation of green affairs. Also, there is a great need to examine the role of cultural differences in respect for green affairs and there is still no cross-cultural model in the area that is even more necessary in Iran due to ethnicity and even different religions. Therefore, in future research, it is suggested to compare universities and green organizations with nongreen organizations.

agenda,” Intl J. of Mgmt. reviews, 15 (1) 1-14 (2012). http://dx.doi.org/10.1111/j.1468-2370.2011.00328.x.

5) C.J.C. Jabbour, F.C.A. Santos and M.S. Nagano, "Contributions of HRM throughout the stages of environmental management: methodological triangulation applied to companies in Brazil," Intl J. of $\begin{array}{lllll}H R M, & 21 & \text { (7) } & 1049-1089 & \text { (2010). }\end{array}$ DOI/abs/10.1080/09585191003783512.

6) C. Ichniowski, K. Shaw and G. Prennushi, "The Effects of Human Resource Management Practices on Productivity: A Study of Steel Finishing Lines”, The American Ecmc. Review, 87 (3) 291-313 (1997).

7) H. Mendelson, and R.R. Pillai, "Information Age organizations, dynamics and performance”, J. Ecmc. Behavior and Org, 38 253-281 (1999).

8) C.J. Collins and K.D. Clark, "Strategic Human 
Resource Practices, Top Management Team Social Networks, and Firm Performance: The Role of Human Resource Practices in Creating Organizational Competitive Advantage”, Acad. Mgmt. J., 46 (6) 740-751 (2003).

9) I. Ehnert, "Sustainability \& human resource management: reasoning and applications on corporate websites,” Eur. J. Int. Mgmt, 3 (4) 419-437 (2009). doi.org/10.1504/EJIM.2009.028848.

10) D. W.S. Renwick, T. Redman, C. J.C. Jabbour, M. Muller-Camen and A. Wilkinson, "Contemporary developments in Green (environmental) HRM scholarship,” Intl J. of HRM, 27 (2) 114-128 (2016). http://dx.doi.org/10.1080/09585192.2015.1105844.

11) B. F. Daily and S. Huang, "Achieving sustainability through attention to human resource factors in environmental management,” Intl. J. of Oprtn. \& Prdc. Mgmt., $21 \quad$ (12) 1539-1552 (2001). http://dx.doi.org/10.1108/01443570110410892.

12) J. Patil and A.P. Sarode, "Green human resource management: Role of HR managers to achieve sustainability”, Intl J. of Creative Research Thoughts (IJCRT), 6 527-531 (2018).

13) A. Hamilton, D.A. Gioia, "Fostering sustainabilityfocused organizational identities. In Roberts LM, Dutton JE (Eds.)", Fostering sustainability-focused organizational identities, first edition, Routledge, New York, (2009).

14) W. O'Donohuea, N. Torugsa, “The moderating effect of 'Green' HRM on the association between proactive environmental management and financial performance in small firms," the Intl J. of HRM, Routledge, $27 \quad$ (2) 239-261 (2016). http://dx.doi.org/10.1080/09585192.2015.1063078.

15) J. Milliman, "Leading-Edge Green Human Resource Practices: Vital Components to Advancing Environmental Sustainability,” Environmental Qulty Mgmt, Wiley, 23 (2) 31-45 (2013). DOI: I0.i002/tqem.21358.

16) B. Shahriari, A. Hassanpoor, A. Navehebrahim and S. Jafarinia, "A systematic review of Green human resource management," EVERGREEN Joint J. of Novel Carbon Rsrce. Scins. \& Green Asia Strtgy. 6 (2) 177-189 (2019).

17) B. Shahriari, A. Hassanpoor, A. Navehebrahim and S. Jafarinia, "Designing a Green Human Resource Management Model for higher education industry (Case Study: Tehran's universities)," Kharazmi University, Tehran. (2019).

18) W. Wehrmeyer, “Greening people," Greenleaf Publishing, Sheffield, (1996).

19) D. Renwick, T. Redman and S. Maguire S, "Green HRM: A Review, Process Model, and Research Agenda," University of Sheffield Management School, (2008). http://www.sheffield.ac.uk/content/1/c6/08/70/89/20 08-01.pdf.
20) E. Renwick and C. Casazza Herman, "Sustainability and employee engagement: Which drives which? In E. Cohen (Ed.). CSR for HR: A necessary partnership for advancing responsible business practices”, Greenleaf Publishing, Sheffield, England, (2010).

21) H. Opatha and A. Arulrajah, "Green Human Resource Management: Simplified General Reflections,” Intl Buss Research, 7 (8) 101-112 (2014). Doi: 10.5539/ibr.v7n8p101.

22) S. Ahmad, "Green Human Resource Management: Policies and Practices,” Cogent Buss \& Mgmt, 2 1-13 (2015). http://dx.doi.org/10.1080/23311975.2015.1030817.

23) Y. Joong Kim, W. Gon Kim, H.M. Chio and K. Phetvaroonb, "The effect of green human resource management on hotel employees' eco-friendly behavior and environmental performance”, Int. J. Hospitality Mgmt., $79 \quad 83-93 \quad$ (2019). https://doi.org/10.1016/j.ijhm.2018.04.007.

24) S. Leidner, D. Baden and M. Ashleigh, "Green (environmental) HRM: aligning ideals with practices,” Personnel review, 48 (5) 169-1185 (2019). doi.org/10.1108/PR-12-2017-0382

25) D. D. Thu Pham and P. Paille, "Green recruitment and selection: an insight into green patterns,” Intl J. of Manpower, 41 (3) 258-272 (2019). DOI 10.1108/IJM-05-2018-0155.

26) C. M. Mathapati, "Green HRM: A strategic facet”, Tactful Mgmt. Research J., 2(2) 1-6. (2013).

27) V. Muster and U. Schrader, "Green work-life balance: A new perspective for Green HRM, "Zeitschrift Fur Personalforschung, 25 140-156 (2011).

28) Y. Mohd Yusoff, N. Zahiyah Othman, Y. Fernando and A. Amran, "Conceptualization of Green Human Resource Management: An Exploratory Study from Malaysian-based Multinational Companies,” Intl J. of Buss. Mgmt and Ecmc Research (IJBMER), 6 (3) 158166 (2015).

29) S. Dutta, "Greening people: A strategic dimension," ZENITH: Intl. J. of Buss. Ecmcs. \& Mgmt Research, 12 (2) 143-148 (2012).

30) Da-Yeh University website, http://green.dyu.edu.tw/en.

31) W. Zhao and Y. Zou, "Green university initiatives in China: a case of Tsinghua University,” Intl. J. of Sustainability, 16 (4) 491-506 (2015). DOI: 10.1108/IJSHE-02-2014-0021.

32) "The Iranian Society for Green Management," retrieved from http:www.iran-gma.com/awards-andcertificates/2110/.

33) E. Strauss and J. Corbin, "Principles of Qualitative Research: Techniques and Processes of Underground Theory Production", translated by Ebrahim Afshar, Tehran: Ney Publishing. (2012).

34) I. Holloway and S. Wheeler, "Qualitative research in nursing and healthcare,” 3rd e.d., Wiley, U.K., (2010). 